\title{
Ecological Offence: Legislative Review of the Post-Soviet Countries, Europe, the Usa, Japan
}

\author{
Gauhar Rustembekovna Rustemova
}

Amangaliy Mukashevich Bytymbayev

Almaty Academy of the Ministry of Internal Affairs of the Republic of Kazakhstan, Kazakhstan, 050060 Almaty, Utepov Street, 29; Email: amangaliy.bytymbayev@yandex.ru

\section{Doi:10.5901/mjss.2015.v6n5s2p85}

\begin{abstract}
The aim of the research is problem statement and comprehensive analysis of the legal combating the crimes against environmental safety. The ecological situation in the Republic of Kazakhstan stipulates the need to change the conception of social danger of the ecological offences. The problems of legislation on the preservation of nature in general reflect the social and legal situation in the Republic of Kazakhstan. The contemporary legislation and normative legal documents are unstable, contradictory, deficient and mirror the lack of coordination in legislation. The present study establishes and comprehensively explores the problem of legal combating the crimes against environmental safety. A serious theoretical research is required for proper understanding and evaluation of socially dangerous deeds, stipulated in the Criminal Code of the Republic of Kazakhstan. The study summarizes the progressive experience of the European countries, the USA and Japan in this direction. The attention is focused on the necessity to secure the legal notion of the crimes against environmental safety and to introduce the institution of criminal liability of legal entities for the purpose of creation of the effective mechanisms for combating environmental crimes. The article concludes on the need to analyze the criminal legal institutions of foreign countries for the best possible experience of the national legislation.
\end{abstract}

Keywords: environmental criminal offenses, environmental crime, environmental safety, preservation of the natural environment, criminal liability of the legal entities.

\section{Introduction}

The great interest in acquaintance with foreign legislation and experience of regulating the interaction between the society and nature is dictated not only by the effort to compare the Kazakhstan and foreign law, but is also important in terms of borrowing positive experience. In addition, in the course of internationalization of the environmental activity and nature management, the process of harmonization of the national legislation is in progress. It is particularly active on the European continent, where the legal institutions are undergoing major changes and make it possible to stabilize the necessary transition, avoiding the critical level of criminality. The national legislation of the Republic of Kazakhstan, being an attribute of the national legal system, is significantly affected by practical legal experience of the foreign countries. Not only the legal systems, but also separate institutions become the main factors, since the practical experience in various regions is historically unique. Therefore, the issues of analysis of different legal systems and borrowing their progressive experience in effective addressing the problems, existing in Kazakhstan are always relevant.

There are about 200 countries in the modern world. They have different levels of economic development, different environment, and show different approaches to solving environmental problems. At the same time, they share responsibility for the preservation and restoration of a favorable environment for the benefit of the present and future generations. Therefore, protection of the environment and the efficient use of its resources for the benefit of the present and future generations is one of the goals, of great importance for the welfare and economic development of the people of all countries in the world.

The current state of legal combating the environmental offenses in various foreign countries reveals a clear tendency to separation of this category of criminal acts in an individual chapter in a criminal regulatory legal act. The criminal law of the vast majority of countries contains a more or less common set of components of environmental crimes, which can be explained by the uniformity of problems facing these countries in the field of legal combating them.

Due to their gravity, the environmental crimes have become an actual international problem that require timely and adequate tools to solve them. Therefore, in our opinion, the study of the accumulated legislative experience in combating 
environmental crimes in the foreign countries is necessary from a scientific and practical point of view.

Let us briefly consider the experience of the environmental law in the states of the former Soviet Union, the European countries, the USA and Japan.

\section{The Research Methodology and Techniques}

The study was undertaken based on the materialist dialectic approach to the research subject analysis, as a universal technique of reality cognition in its natural historical development. The problem review was also based on a comparative analysis of regulatory legal acts of various states and legal interpretation method of corresponding rules of law.

Furthermore, the study of theoretical research issues took place in consideration of the EU, US and Japan experience in creating environmental legislation and its implementation.

\section{Results and Discussion}

\subsection{The legal regulation of the environmental crimes in the legislation of the former Soviet countries.}

Given the severity of the environmental problems in the former USSR and the underdevelopment of the environmental legislation, the objective of the environmental cooperation in the Commonwealth of Independent States (CIS) is relevant. The interstate cooperation in the field of environmental protection is carried out both on a bilateral basis and within the framework of the Agreement on cooperation in the field of ecology and environmental protection, signed in February 1992 by Azerbaijan, Armenia, Belarus, Kazakhstan, Kyrgyzstan, Moldova, the Russian Federation, Tajikistan, Turkmenistan, Uzbekistan and Ukraine.

The parties to the Agreement have agreed to develop and conduct a coordinated policy in the field of preservation and use of the lands, soil, minerals, forests, water, air, flora and fauna, the natural resources of the continental shelf, economic zone and the high seas beyond the national jurisdiction, taking into account the agreements, previously signed by the USSR.

An important role in development of the environmental cooperation within the CIS plays the Interparliamentary Assembly. Within its structure, a Department of the environmental protection is established. The most significant guideline of its activities is preparation of the model laws in the field of nature management and environmental protection.

The advisory legislative act "On Environmental Safety" was adopted by the Resolution of the Interparliamentary Assembly of the Commonwealth of Independent States-members on November 2, 1996 (Newsletter of the Interparliamentary Assembly of the CIS member states, 1997). It states that the purpose of the legal regulations in the field of environmental safety is protection of life, health and conditions of human life; protection of society, its material and intellectual values; the natural environment, including air and space, water bodies, mineral resources, land and forest resources, soils, landscape, flora and fauna from the risks arising from the environmental impact of the economic and other activities of the legal entities and individuals, the public authorities and local administrations and their officials.

Environmental security is regarded as a state of safety of the vital interests of individuals, society and natural environment from the threats arising from the anthropogenic and natural impacts. In the Art. 1 of the Environmental Code of the Republic of Kazakhstan the environmental security is treated as a "state of safety of the vital interests and rights of individuals, society and state from the threats arising from the anthropogenic and natural impacts on the environment" (Environmental Code of the Republic of Kazakhstan, 2007). From this definition, we can conclude that the environmental threat is a state hazardous to the security of the vital interests of the individual, society and environment as a result of anthropogenic and natural impacts. Wherein an environmental emergency, environmental disaster and an environmentally dangerous situation are singled out. In the advisory legislative act, it is stated that "The environmental safety is an integral part of the security of the individual, society and state. Implementation of the rights and freedoms of citizens, damaging the rights of other citizens to environmental safety, is not permitted. The impact on the natural environment should not reduce the level of environmental security of the present and future generations" (Resolution of the Interparliamentary Assembly of the States-members of the CIS, 1992).

Thereby, a proposition for the CIS member states is made to refer the abuse of legal provisions in the area of environmental security to the violations of human rights.

The Model Criminal Code of the CIS member states (CIS MCC) has been adopted by the Resolution of the Interparliamentary Assembly of the CIS member states in St. Petersburg on February 17, 1996, it presented the deeds violating environmental safety, and their legal description as environmental crime. In the formation of the criminal legislation of the designated states, the recommendations contained in the CIS MCC were taken into account (The Model 
Criminal Code for the States-members of the CIS, 1996). The independent chapters (sections) regulating environmental crimes are separated in the Criminal Codes of all the CIS member states. In particular, Chapter 28 of the Criminal Code of the Azerbaijani Republic (1999), Chapter 26 of the Criminal Code of the Kyrgyz Republic (1997), Chapter 9 of the Criminal Code of the Republic of Moldova (2002), Chapter 11 of the Criminal Code of the Republic of Kazakhstan (2014).

The Criminal Code of the Republic of Kazakhstan, effective since January 1 2015, provides for the division of criminal offenses into crimes and criminal infractions. In accordance with Part 2, Art. 10 of the Criminal Code, the crime is a committed guilty socially dangerous deed (action or inaction) prohibited by the Criminal Code, under penalty of a fine, corrective labor, restrictions on freedom, imprisonment or the death penalty. And in Part 3 Article 10 of the Criminal Code, the criminal infraction is a committed guilty deed (action or inaction), not presenting great danger to society, causing minor damage or endangering the person, organization, society or the state, which is punishable by a fine, correctional labor, community service, arrest. In this Code, the criminal offenses against environmental security are considered in Chapter 13 "Environmental criminal offenses" (The Criminal Code of the Republic of Kazakhstan, 2014).

This implies that the environmental criminal offense, depending on the degree of public danger and punish ability are divided into environmental crimes and environmental criminal infractions. Under the environmental crime is understood a committed guilty socially dangerous deed (action or inaction) prohibited by Art. 13 of the Criminal Code of the Republic of Kazakhstan, under the penalty of a fine, corrective labor, restrictions on freedom or imprisonment. Under the environmental criminal infraction is understood a committed guilty deed (action or inaction), not presenting great danger to society, causing minor damage or endangering the person, organization, society or the state, which is punishable by a fine, correctional labor, community service, arrest. Furthermore, two articles on environmental criminal offenses supplement the Criminal Code of the Republic of Kazakhstan: Art. 334 "Unauthorized use of mineral resources" and Art.336 "Violation of the fish stocks conservation regulations" (The Criminal Code of the Republic of Kazakhstan, 2014).

The criminal codes of the Baltic States (Latvia, Lithuania and Estonia) also contain regulations on the environmental crimes, and provide for the division of socially dangerous acts into crimes and criminal offenses. The crimes are punishable by imprisonment; the offenses entail the arrest and milder punishment. The environmental offenses are specified in different sections of the Republic of Latvia Criminal Code, but mostly they are concentrated in the Chapter XI "Criminal offences against the environment". However, the crimes stipulated in Article 222 "Violation of veterinary provisions" and 223 "Violation of Provisions Regarding Prevention of Crop Disease and Infestation" are referred to criminal acts in the national economy (The Criminal Code of Latvia, 1998). The Criminal Code of the Republic of Lithuania allocates a separate chapter XXXVIII "Crime and misdemeanours against the environment and human health" (The Criminal Code of the Republic of Lithuania, 2000).

One of the important differences of the Criminal Codes of the Baltic states from other post-Soviet states is the prosecution of not only physical but also legal entities.

For instance, according to the Criminal Code of the Republic of Lithuania, a legal entity shall be held liable for the criminal acts committed by a natural person solely where a criminal act was committed for the benefit or in the interests of the legal entity by a natural person acting independently or on behalf of the legal entity, provided that he, while occupying an executive position in the legal entity, was entitled to represent the legal entity, or to take decisions on behalf of the legal entity, or to control activities of the legal entity (Art. 20). A legal entity may be held liable for criminal acts also where they have been committed by an employee or authorized representative of the legal entity as a result of insufficient supervision or control over him. A legal entity may be sentenced to a fine, restriction of activities and liquidation. In this case, criminal liability of a legal entity shall not release from criminal liability a natural person who has committed, organized, instigated or assisted in commission of the criminal act (Pavilonis V., 2003).

In 2005, the Criminal Code of the Republic of Latvia was supplemented by a chapter "Compulsory measures applicable to legal entities". Liquidation of the enterprise, limitation of rights, confiscation of property, fines and reparation of damages are provided in the capacity of such measures. The court in its judgment, recognizing proven that an individual has committed a crime for the benefit of the legal entity, and the last was aware of the act, but did nothing to prevent it, decides on application of compulsory measures. Thus, coercive measures that are not criminal penalties are applied to the legal entities in Latvia. Moreover, they are enforced only in case of conviction of an individual who acted criminally in the best interests of the legal entity (Krastinsh U. Ya., 2006).

The environmental crimes are located in Chapter 20 "Offences against environment" of the Criminal Code of the Republic of Estonia: Violation of land use requirements or procedure for maintenance of land cadastre (§ 283), Violation of procedure for utilization of natural resources or procedure for maintenance of records on pollution (\$366), Illegal cutting of trees or shrubs (§356), damaging or destruction of trees or shrubs (§354), Damaging or destruction of trees or shrubs through negligence (§ 355) (The Criminal Code of the Republic of Estonia, 2001). There is stipulated a liability of a legal 
entity for a crime or misdemeanor.

Since the Criminal Code of Uzbekistan was one of the first, enacted in the former Soviet space, its first edition was quite imperfect, it did not reflect all the needs of the state with a market economy; therefore, in 2001, there was made a substantial revision of the Code, that was aimed to bring the code into line with the generally recognized principles and norms of international law, to liberalize the responsibility, criminalize new and decriminalize the former crimes, to introduce the latest achievements in criminal jurisprudence (Luneev V. V., 2005). Section 4 of the Criminal Code of Uzbekistan contains only the area where the "crimes in the field of ecology" are committed, and Chapter XIV "Crimes related to environment protection and conservancy" (The Criminal Code of the Republic of Uzbekistan, 1994).

The Criminal Code of Armenia is largely based on the provisions of the Model Penal Code for the CIS member states. The legislator has reflected the social orientation of a deed, violating the environmental laws, and thereby determined the object of the crime, which, in our opinion, is more preferable. For example, Chapter 27 and Section 10 of the Criminal Code of the Republic of Armenia are titled "Crimes against the environmental safety" (The Criminal Code of the Republic of Armenia, 2008).

The Criminal Code of Georgia is based on the provisions of the Model Penal Code for the CIS member states in much the same way; also, many rules are borrowed from the Criminal Code of the Russian Federation of 1996, although the experience of the Criminal Code of the Georgian SSR of 1960 is taken into account, as well as international norms and features of the socio-political situation in Georgia. Proceeding from the title of the section $X$ "Crime against environmental protection and exploitation of natural resources" of the Criminal Code of Georgia (The Criminal Code of Georgia, 1999), we can say that the legislator indicated two groups of environmental crimes:

- against the rules of environmental protection;

- $\quad$ against the rules of using natural resources. Nevertheless, the title of the chapter XXXVI of this section shows the merger of a narrow circle of acts against the environment protection.

The peculiarity of the Criminal Code of Georgia is that the environmental crimes are recognized: failure of an assigned official to report about the dumping at sea of substances harmful to human health or living organisms or other waste or materials (Art. 294); activities of the first category without a permit (Art. 306).

The Criminal Code of the Republic of Belarus (1999) and the Criminal Code of the Republic of Tajikistan (1998) direct the considered crime against the environmental safety and the environment. The Criminal Code of Belarus is largely based on the provisions of the Model Penal Code for the CIS member states; also many rules borrowed from the Criminal Code of the Russian Federation of 1996, although in general, the code is described as quite independent and theoretically conceived. One of the peculiarities of the Criminal Code of Belarus is that the note of the relevant chapter enshrines a legal concept of crimes against environmental safety. "The crimes against environmental safety and the natural environment are considered committed intentionally or negligently socially dangerous acts causing or likely to cause harm to the land, waters, mineral resources, forests, flora and fauna, air, and other natural objects, referred to as such by the legislation on the protection of the environment, regardless of ownership" (Volzhenkin B. V., 2000).

The Criminal Code of Tajikistan is also largely based on the provisions of the Model Criminal Code for the CIS member states; many rules are borrowed from the Criminal Code of the Russian Federation of 1996. Including standards of environmental crimes.

\subsection{Environmental crimes in the legislation of the European countries, the USA and Japan}

The European states, as well as the US and Japan have a more developed environmental legislation than the CIS member-states. The study of the environmental law of the USA, Japan, Germany, France, Britain and other economically developed countries is of particular interest. They gained a lot of experience in creating environmental legislation and its implementation.

Due to introduction of the scientific and technical achievements, they have highly developed industry, agriculture, transport and energetics that present a powerful and basic factor of the negative impact on the environment. The urbanization processes in these countries have always been very intense. As a result, the environment in many of them was rated critical by the end of the 60s. Primarily, the high levels of pollution revealed the environmental crisis. Then came the realization that pollution is harmful not only to human health, but also is a hindrance in the economy development.

The degradation of nature in the United States, Japan, Germany, France, Britain and other economically developed countries resulted in creation of environmental legislation system. At the same time, they create state structures, designed to ensure compliance with this legislation. It is important to stress that the legislative process regarding the interaction between society and nature is very dynamic. If necessary, amendments and additions are 
introduced into the adopted laws. The environmental laws are sometimes adopted in response to acute environmental problems.

The public environmental movement has served and still serves as an important impetus for development of the environmental legislation in these countries.

Both environmental legislation and the Criminal Code (for example, in Germany) regulate criminal liability for environmental crimes. Thus, a criminal fine of up to 25 thousand USD per day of violation, or imprisonment up to 1 year or both may be imposed for willful violation of specific provisions of the USA law on the quality of water, air and wastes. Repeated violation is punished by a fine of up to 50 thousand USD per day of violation, or imprisonment for up to 2 years. Criminal liability for environmental crimes in the USA comes for an intentional violation of the law.

Criminal liability is stricter in the criminal law of Germany. For instance, violation of waste disposal is liable to imprisonment not exceeding three years or a fine, according to section 326 of the Criminal Code of Germany. Such alteration of agricultural and other lands that leads to impossibility to use them for a long time shall be punished with imprisonment not exceeding five years or a fine.

Compensation for damage, caused by the environmental legislation violation, is one of the most difficult problems in the environmental law.

The original version of the legal regulation for environmental damage compensation has been used in connection with the mass poisoning with mercury and cadmium compounds in Minamata Bay in Japan. In December 1969, the Law on special measures to assist the victims of pollution has been adopted, and in 1973 - the Law on compensation for damage caused to public health by pollution. These laws provide the victims with compensation of expenses for treatment and care; rule out the need to institute legal proceedings against the culpable enterprises and remove the burden of proof.

The mechanism of damage compensation regulation includes the following. A governmental prescription establishes the areas of considerable water and air pollution. A municipal commission is created in the corresponding area for registration of pollution victims. The victims must undergo a medical examination and apply for compensation. After the official registration, the municipal authorities are obliged to pay for medical expenses of the victim. A person is considered the victim of pollution, if has been living or staying in the area for a certain period stipulated by the Law. The state collects a tax from the polluter. It is calculated based on the contribution of a particular company in pollution. State bodies set the tax after the event of pollution and harm to human health.

Chapter 15, Art. 142-147 of the Criminal Code of Japan "Crimes relating to drinking water" (The Criminal Code of Japan, 1907) provides the criminal legal protection only for water. The Chapter consists of the following articles: Contamination of pure water (Art. 142); Contamination of water supply (Art. 143); Poisoning of pure water (Art. 144); Evocation of death or bodily injury in result of pollution or poisoning of pure water (Art. 145); Poisoning water and evocation of death as a result of the act (Art. 146); Damage to water supply (Art. 147).

The Criminal Code of the Federal Republic of Germany assigns two traditionally environmental crimes - poaching (§ 292), and illegal fishing (§ 293) to the mercenary criminal acts (section 25) (The Criminal Code of the Federal Republic of Germany, 1871). Misappropriation or conversion to a third party of the things, related to hunting rights or the right to fish, its damage or destruction (Part Two of those articles) are considered criminal along with hunting and poaching. Section 29 "Punishable acts against the environment" combines the crimes against the environment. In general, they are known in the criminal legislation of Kazakhstan. Therefore, there is some specificity in the criminalization of socially dangerous acts. For example, release of non-ionizing rays (§ 325a), and illegal exploitation of plants (§ 327) are considered criminal.

The Criminal Code of Spain locates the crimes against natural resources and the environment in Chapters III and IV of Section XVI "On the crimes related to the management of areas, and historical heritage and the environment protection". Chapter III sets the general environmental crimes: violation of the law and other general provisions on environmental protection (Art. 325); positive assessment to provide a clearly illegal license, which justificates the functioning of polluting industries or jobs, or concealment of violations of laws or general provisions regulating the relations in the field of environmental protection (Art. 329); causing serious damage to one of the elements, which serves to increase the value of the protected natural area (Art. 330).

Chapter IV of this section includes "The crimes related to the protection of flora and fauna". The objects of protection are the same objects of flora and fauna as in Kazakhstan, but there are some differences. For example, environmental crimes include illegal trade in any endangered or just propagating species or subspecies of plants (Art. 332); import or release to freedom of non-native plants or animal species that harm the biological equilibrium (Art. 333); trade in wild animals or transportation of them or their remains (Art. 334) (The Criminal Code of Spain, 1995).

According to the Swiss Criminal Code distribution of epizooty (Art. 232) and pests dangerous for agriculture or 
forestry (Art. 233), and contamination of drinking water are recognized not as environmental crimes but acts that damage public health (Section 8) (The Swiss Criminal Code, 1937).

The Danish Criminal Code has only a few regulations on environmental crimes, which are located in Chapter 20 "The crimes causing danger to society" (creating the risk of transmission, or spread of the disease among domestic animals, cultivated or benefiting plants - § 192). And in Chapter 21 "Various acts causing public harm" (in violation of the Law "On the environment": a) pollution of air, water, soil or subsoil, resulting in significant harm or an imminent threat of harm to the environment; b) storage or disposal of similar substances wastes, which cause significant damage or immediate threat to the environment - § 196) (Danish Criminal Code, 1930).

The Criminal Code of the Republic of Bulgaria is composed in similar legislative technique. In section III "Crimes against people's health" of Chapter XI "Overall dangerous crimes" the provisions on liability for environmental crimes are well represented. These include: pollution of water sources, basins, ground waters and the territorial or inland sea waters, the soil and the air (Part 1, Art. 352); failure in designing, constructing or operating drainage or irrigation systems to take the necessary measures for prevention of hazardous pollution of potable water supply zones, or for raising of ground water levels in residential and resort areas (Part 2, Art. 352); pollution by petrol products or derivatives of territorial and inland sea waters in zones, established by international agreement to which the Republic of Bulgaria is a party (Part 1, Art. 352a); failure of the captain of a ship or another vessel to inform immediately the nearest port about dumping into the waters of petrol products or derivatives, or of other substances hazardous to people, animals or plants (Part 4, Art. 352a); failure of the captain or another commanding officer of a vessel to fulfil their obligations to enter in the vessel documents a report on operations with substances, hazardous to people, animals or plants, or entering therein untrue information about such operations, or refusal to present such documents to the respective officials (Part 5 Art. 352a); putting or releasing of a permit for an enterprise or thermal power station to be put into operation before putting into operation of the necessary water treatment equipment (Art. 353); concealing or distributing untrue information about the state of the environment and the components thereof atmospheric air, water, soil, sea areas (Art. 353a); carrying over the border of the country of hazardous waste in violation of international agreement to which the Republic of Bulgaria is a party (Art. 353b, 352a); violation or breach of duty for gathering, storage, transportation and elimination of hazardous waste (Art. 353c) (The Criminal Code of the Republic of Bulgaria, 1968).

The crimes under consideration are concentrated in a separate chapter XXII "Crimes against the environment" in the Criminal Code of Poland. In addition to the "traditional" acts, similarly to the Criminal Code of the Republic of Bulgaria, carrying over the border of hazardous waste or substances is recognized criminal (§2 Art. 183). Moreover, destruction, substantial damage or considerable reduction in the cost of natural areas or objects, protected by law, which have caused substantial harm are acknowledged criminally liable ( $\$ 1$ Art. 187). Construction on territory, protected from natural or local historical reasons, or adjacent thereto, despite the rules; or the completion of construction of existing buildings or economic activities that threaten the environment (Art. 188) (The Criminal Code of the Republic of Poland, 1997).

The Austrian Criminal Code (1974) places the criminal acts against the environment in one - the seventh section with generally dangerous criminal acts, such as arson, careless creation of fire hazards, intentional and negligent creation of a general threat etc. Environmental crimes in Austria, in particular, include the intentional and negligent infliction of harm to the environment $(\S 180,181)$, a serious infliction of harm associated with the use of noise $(\S 181, a)$, waste management and delivery, intentionally threatening environment ( $\S 181, b)$, threatening the status of an animal or plant world (§ 182) etc. At the same time, some typical environmental offences are contained in the Austrian Criminal Code and in section of criminal acts against other people's property: infringement of another's right to hunt and fish (§ 137), heavy violation of another's right to hunt and fish (§138), the use of force by poacher (§ 140).

Summarizing the state of legal combating of environmental crimes in various foreign countries, it is easy to find a clear tendency for this category of criminal acts to separate into individual chapters of the leading criminal codifying normative legal act. In most cases, the criminal legislation of these countries contains more or less general (common) set of environmental crimes compositions, explainable by uniformity of the problems faced by these countries in the field of criminal legal combating them. In certain cases, depending on the particular significance of a natural object (social, economic, cultural, recreational), the Criminal Code of a particular country considers the offenses, related to inappropriate use and abuse of the objects in more detail (forests - in Latvia and Estonia, the water - in Japan, etc.). At the same time, the attention is drawn to the absence of a specific article on responsibility for the crimes of "ecocide" in the criminal codes of foreign countries. These countries still have a chance to incorporate this article in their criminal laws, in the case of adoption and ratification of relevant international instruments, as part of the transformation. 


\section{Conclusion}

The experience of the foreign countries in introduction of the criminal liability institute of the legal entities is generally positive (Norway, the Netherlands, Finland, France, the USA and others). As mentioned above, in this regard the experience of Latvia is interesting in the post-Soviet area. The Criminal Code of Latvia does not change the rules of qualification and punishing the acts of individuals and criminal liability of the legal entities is not designed as a punishment, but a coercive influence.

As the experience of foreign countries shows (the criminal liability of the legal entities is established in Germany, Denmark, France, Belgium, Japan, the USA, the Netherlands, Austria, Norway, Romania, Moldova and Lithuania), the introduction of criminal liability of legal entities is necessary to create effective mechanisms to counter environmental crime.

The liability of legal entities shall increase the compensation level for the damage to the environment caused by criminal offences, since the presence of the criminal liability of legal entities will ensure the application of proprietary sanctions directly to them.

There can be applied the following sanctions, such as fines, deprivation of the right to engage in certain activity or liquidation of a legal entity.

The environmental crimes and environmental offenses, as a form of criminal infringements constitute a sufficiently complex problem.

The environmental offenses, providing legal, i.e. criminal liability in such cases, require a precise detailed qualification that complies with the principles of legality and validity. A criminal offense is secured with independent sector laws, according to the degree and level of public danger, in order that the inevitability of punishment becomes a feasible principle, corresponding to the goals and objectives of the criminal law.

The features and peculiarities of the environmental offenses, as a real threat to national security and public safety are reflected in the legislative consolidation of particular generic and specific objects of the offense. The criminal liability for environmental offenses requires not only the criminal regulations, i.e. specific sanction article of the criminal law, but also the practical operational experience in combating the environmental offenses. The national experience in dealing with environmental offenses is often based on the best legal tools and international experience. It is necessary to analyze the criminal legal institutions of the foreign countries for the best possible experience of the national legislation.

\section{References}

Krastinsh U. Ya. (2006) The issues of application of the forced measures to legal entities. The constitutional foundations of the criminal law. Proceedings of the I All-Russian Congress of criminal law on the Decade of the Criminal Code of the Russian Federation. Moscow, 294-297.

Luneev V.V. (2005) Crime of the XX century: global, regional and Russian tendencies. Moscow. Wolters Kluwer.

Newsletter of the Interparliamentary Assembly of the CIS member states. (1997) The documents of the meeting of the Interparliamentary Assembly of the States-members of the Commonwealth of Independent States. St. Petersburg, 1-2 November, 1996, 12, 201221.

Pavilonis V. (2003) The Criminal Code of the Republic of Lithuania. St. Petersburg. Legal Center Press.

Resolution of the Interparliamentary Assembly of the States-members of the Commonwealth of Independent States of December 29, 1992. On the recommendatory legislative act "On the principles of environmental safety in the Commonwealth" [Online] Available: http://busel.org/texts/cat9ur/id5cwlfuz.htm.

The Criminal Code of Georgia of July 22, 1999 (Amended 2011) [Online] Available: http://gca.ge/uploads/files/5._sakartvelos_sisxlis_ samartlis_kodeqsi.pdf.

The Criminal Code of Japan, of April 24, 1907 (Amended 2007) [Online] Available: http://constitutions.ru/?p=407

The Criminal Code of Latvia of September 28, 2005 (Amended 2013) [Online] Available: http://likumi.lv/doc.php?id=88966.

The Criminal Code of Spain on November 24, 1995 (Amended 20119) [Online] Available: http://www.legislationline.org/download/action/ download/id/5160/file/Spain_Criminal_Code_Codigo_Penal.pdf.

The Criminal Code of the Federal Republic of Germany on May 15, 1871 (Amended 2009) [Online] Available: http://www.stgb.de/ gesetzestexte.html

The Criminal Code of the Kyrgyz Republic of September 18, 1997 (Amended 2006) [Online] Available: http://www.prokuror.kg/index. php? Itemid=109\&catid=82\&id=767:ugolovnyj-kodeks-kyrgyzskoj-respubliki\&lang=ru\&option=com_content\&view=article.

The Criminal Code of the Republic of Armenia of June 21, 2008 (Amended 2013) [Online] Available: http://www.parliament.am/ legislation.php?sel=show\&ID=1349\&lang=rus.

The Criminal Code of the Republic of Austria of January 23, 1974 (Amended 2013) [Online] Available: http://www.legislationline.org/ download/action/download/id/4868/file/Austria_CC_as_of_\%2004.11.2013_de.pdf.

The Criminal Code of the Republic of Azerbaijan of December 30, 1999 [Online] Available: http://www.legislationline.org/download/ 
action/download/id/1658/file/4b3ff87c005675cfd74058077132.htm/preview.

The Criminal Code of the Republic of Belarus dated July 9, 1999 (Amended 2015) [Online] Available: http://etalonline.by/?type=text\& regnum=HK9900275\#load_text_none_1.

The Criminal Code of the Republic of Bulgaria of March 15, 1968 (Amended 2010) [Online] Available: http://www.vks.bg/vks_p04_ 04.htm.

The Criminal Code of the Republic of Estonia of June 6, 2001 (Amended 2013) [Online] Available: https://www.riigiteataja.ee/akt/22221.

The Criminal Code of the Republic of Kazakhstan of July 3, 2014 [Online] Available: http://adilet.zan.kz/rus/docs/K970000167.

The Criminal Code of the Republic of Lithuania of September 26, 2000 (Amended 2010) [Online] Available: http://crimpravo.ru/ codecs/litva/2.doc.

The Criminal Code of the Republic of Moldova of April 18, 2002 (Amended 2009) [Online] Available: http://lex.justice.md/ru/331268.

The Criminal Code of the Republic of Poland of January 1, 1997 (Amended 2003) [Online] Available: http://kodeks.ws/karny.

The Criminal Code of the Republic of Tajikistan of May 21, 1998 [Online] Available: http://www.prokuratura.tj/new/tj/docs/zakon/349kodeksi-chinojatii-chumhurii-tochikiston.html.

The Criminal Code of the Republic of Uzbekistan of September 22, 1994 (Amended 2001) [Online] Available: http://www.lex.uz/pages/ getpage.aspx?lact id $=111453$.

The Danish Criminal Code of April 15, 1930 [Online] Available: http://www.themis.dk/searchinclude/lovsamling/Straffeloven_ indholdsfortegnelse.html.

The Environmental Code of the Republic of Kazakhstan of January 9, 2007 [Online] Available: http://online.zakon.kz/Document/?doc id $=30085593$.

The Model Criminal Code for the States-members of the Commonwealth of Independent States. Recommendatory legislative act. Adopted February 17, 1996 [Online] Available: http://legislationline.org/documents/section/criminal-codes.

The Swiss Criminal Code of December 21, 1937 (Amended 2014) [Online] Available: http://www.admin.ch/opc/de/classified-compilation/ 19370083/201501010000/311.0.pdf.

Volzhenkin B. V. (2000) The new Criminal Code of the Republic of Belarus. Jurisprudence, 6, 140-152. 